\title{
PENAMBAHAN AMPAS TEH HIJAU FERMENTASI DALAM RANSUM ITIK CIHATEUP SEBAGAI UPAYA PERBAIKAN PROFIL LIPID DARAH
}

\author{
(The Addition of Fermented Green Tea Dregs in Cihateup Ducks Ration as an Effort to \\ Improve the Blood Lipid Profiles)
}

\author{
Andri Kusmayadi ${ }^{1}$ dan Ristina Siti Sundari ${ }^{2}$ \\ ${ }^{1}$ Program Studi Peternakan Universitas Perjuangan Tasikmalaya, \\ Jalan Pembela Tanah Air No. 177, Tasikmalaya, 46115 \\ ${ }^{2}$ Program Studi Agribisnis Universitas Perjuangan Tasikmalaya, \\ Jalan Pembela Tanah Air No. 177, Tasikmalaya, 46115 \\ email: andrikusmayadi@unper.ac.id
}

\begin{abstract}
Green tea dreg has the potential to be used as an additive to poultry feed because it still contains complete and useful nutrients. The aim of this study was to examine the effect of adding fermented green tea dregs into the ration on the blood lipid profile of Cihateup ducks. The research was carried out experimentally to evaluate the blood lipid profile levels of Cihateup ducks consisting of total cholesterol, triglycerides, LDL and HDL. A total of 60 Day-old Cihateup ducks was randomly assigned to 4 treatment groups and 5 replications per treatment. The four treatments were differentiated according to the differences in the percentage of fermented green tea dregs used, namely $0 \%, 1 \%$, $2 \%$ and 3\%, respectively. The significant effects of the treatments study was further tested using the DMRT method. The results showed that the addition of fermented green tea dregs in the diets had a significant effect $(\mathrm{P}<0.05)$ on total cholesterol and LDL levels. However, the parameters of triglycerides and HDL were not significantly affected $(\mathrm{P}>0.05)$. The addition of $3 \%$ fermented green tea dregs in the ration resulted in the lowest blood cholesterol and LDL of the Cihateup ducks.
\end{abstract}

Keywords: tea dregs, fermentation, duck, cholesterol, lipid profile.

\section{ABSTRAK}

Ampas teh hijau berpotensi dijadikan sebagai imbuhan pakan unggaskarena masih mengandung nutrien yang cukup lengkap dan bermanfaat. Penelitian bertujuan untuk mengkaji pengaruh ampas teh hijau fermentasi (ATHF) terhadap profil lipid darah itik Cihateup. Penelitian dilaksanakan secara eksperimen untuk menguji kadar profil lipid darah itik Cihateup yang terdiri atas kolesterol total, trigliserida, LDL dan HDL. Sebanyak 60 ekor DOD itik Cihateup dikelompokkan secara acak pada 4 kelompok perlakuan dan 5 ulangan. Keempat perlakuan tersebut berupa perbedaan persentase penggunaan ampas teh hijau fermentasi yang terdiri atas $0 \%, 1 \%, 2 \%$ dan $3 \%$ ATHF. Penelitian menggunakan rancangan acak lengkap dan diuji lanjut menggunakan metode DMRT. Hasil penelitian menunjukkan penambahan ampas teh hijau fermentasi berpengaruh nyata $(\mathrm{P}<0,05)$ terhadap kadar kolesterol total dan LDL. Adapun pada parameter trigliserida dan HDL tidak berbeda nyata $(\mathrm{P}>0,05)$. Penambahan ampas teh hijau fermentasi 3\% dalam ransum diperoleh kolesterol dan LDL darah paling rendah.

Kata Kunci: ampas teh, fermentasi, itik, kolesterol, profil lipid.

\section{PENDAHULUAN}

Teh merupakan salah satu jenis produk minuman yang banyak dikonsumsi masyarakat dunia termasuk Indonesia. Tingkat konsumsi teh di Indonesia cukup tinggi dan semakin meningkat setiap tahunnya, pada Tahun 2019 diprediksi meningkat sebesar 3\% dibandingkan tahun 2018 (Martina dan Abdilla, 2020).
Peningkatan konsumsi teh di Indonesia disebabkan oleh mudah diterimanya oleh seluruh lapisan masyarakat, berkembangnya sektor perekonomian, majunya bidang pendidikan dan berubahnya gaya hidup masyarakat (Handayani dkk., 2014). Salah satu jenis teh yang paling banyak dikonsumsi di Indonesia yaitu teh hijau. Dengan meningkatnya tingkat konsumsi teh tersebut maka dipastikan 
akan dihasilkan banyak ampas teh hijau yang belum dimanfaatkan.

Ampas teh dapat bersumber dari rumah tangga pengkonsumsi teh maupun limbah pabrik pengolahan minuman teh. Ampas teh dapat dihasilkan sampai 166.000 ton/tahun dari setiap pabrik pengolah teh (Saqifah dkk., 2010; Handayani dkk., 2014). Teh hijau mengandung senyawa polifenol dengan aktivitas antioksidan tertinggi dibandingkan teh oolong maupun teh hitam (Fajar dkk., 2018). Perbedaan dari ketiga jenis teh tersebut adalah teh hijau tanpa melalui proses fermentasi, teh oolong telah melalui setengah proses fermentasi dan teh hitam telah difermentasi secara sempurna (Nindyasari, 2012). Teh hijau dilaporkan memiliki zat yang dapat menurunkan tingkat absorpsi lipid seperti trigliserida, kolesterol dan komponen lipolifik lainnya di dalam usus halus.

Ampas teh hijau dilaporkan masih mengandung senyawa bioaktif yang sama dengan kandungan teh hijau. Senyawa katekin pada teh hijau mengandung antioksidan dan epigallocatechin gallate (EGCG) yang dapat mengganggu emulsifikasi dan pencernaan serta penyerapan lipid di dalam usus (Ngantung dkk., 2020). Yulianti dkk. (2013) melaporkan bahwa terdapat hubungan antara kadar kolesterol darah dengan kolesterol daging. Kolesterol darah yang rendah akan menghasilkan kolesterol daging yang rendah pula. Penelitian sebelumnya dilaporkan bahwa ampas teh hijau mengandung tannin dan serat kasar yang relatif tinggi sehingga dapat menghambat kecernaan nutrien oleh karena itu perlu diproses terlebih dahulu dengan cara fermentasi untuk mengurangi kadar tannin dan serat kasar. Penambahan ampas teh hijau fermentasi pada pakan itik dapat memperbaiki pertambahan bobot badan, konversi pakan dan IOFC (Kusmayadi dkk, 2020). Penelitian bertujuan untuk mengetahui pengaruh penambahan ampas teh hijau fermentasi terhadap profil lipid darah itik Cihateup.

\section{MATERI DAN METODE}

\section{Materi}

Penelitian ini menggunakan Itik Cihateup berumur sehari (DOD) sebanyak 60 ekor berjenis kelamin jantan, ampas teh hijau, EM4 sebagai fermentor, bahan pakan basal, air minum, kandang kelompok, tempat pakan, tempat minum, timbangan digital dan seperangkat alat uji profil lipid darah.

\section{Rancangan dan prosedur penelitian}

Ampas teh hijau yang didapatkan dari pabrik pengolah teh di Tasikmalaya selanjutnya difermentasi menggunakan EM4 pada suhu ruang selama 7 hari dan dilakukan secara anaerob. Produk ampas teh hijau hasil fermentasi tersebut selanjutnya diformulasikan ke dalam 4 kelompok perlakuan pakan itik Cihateup berdasarkan rancangan acak lengkap (RAL) pola searah. Keempat kelompok perlakuan pakan tersebut diulang sebanyak 5 kali dan dirancang menggunakan level penambahan ampas teh hijau yang berbeda yaitu 0\% ATHF (K1), 1\% ATHF (K2), 2\% ATHF (K3) dan 3\% ATHF (K4). Pemeliharaan itik Cihateup dilakukan selama 8 minggu (56 hari) dan pada umur panen tersebut selanjutnya diuji kadar profil lipid darahnya.

\section{Parameter yang diukur}

Parameter yang diukur yaitu profil lipid darah yang terdiri atas kolesterol total, trigliserida, LDL dan HDL. Sampel darah itik diambil dari 1 ekor itik secara acak dari masingmasing unit percobaan yang berisi 5 ekor itik. Darah diambil pada hari ke-56 sebanyak $\pm 2 \mathrm{ml}$ dari bagian vena pektoralis itik. Sampel darah itik yang sudah diambil, ditampung di dalam tabung eppendorf dan selanjutnya disimpan di dalam kotak pendingin. Sampel darah yang siap dianalisis selanjutnya disentrifuse untuk mendapatkan plasma darahnya dengan kecepatan $4000 \mathrm{rpm}$ selama 10 menit. Kadar kolesterol total, HDL dan LDL darah itik dianalisis menggunakan metode CHOD-PAP sedangkan kadar trigliserida menggunakan metode GPO-PAP (Ermayanti dkk., 2018).

\section{Analisis data}

Data yang diperoleh diolah menggunakan analisis ragam (ANOVA) dan dilanjutkan dengan uji Duncan's Multiple Range Test (DMRT) apabila terdapat perbedaan nyata dengan bantuan perangkat lunak SPSS versi 25.0.

\section{HASIL DAN PEMBAHASAN}

Profil lipid darah itik Cihateup yang diberi pakan mengandung ampas teh hijau fermentasi tersaji pada Tabel 1. Nilai kadar kolesterol total itik Cihateup hasil penelitian berkisar antara 152,28-171,53 mg/dl. Kadar kolesterol total hasil penelitian masih dalam kisaran normal kadar kolesterol total itik yang berkisar antara 100 $250 \mathrm{mg} / \mathrm{dl}$ (Thrall et al., 2012). Kadar kolesterol 
Tabel 1. Kadar kolesterol total, LDL, trigliserida dan HDL itik Cihateup yang diberikan ampas teh hijau fermentasi

\begin{tabular}{lcccc}
\hline \multirow{2}{*}{ Parameter } & \multicolumn{4}{c}{ Perlakuan } \\
\cline { 2 - 5 } & K1 & K2 & K3 & K4 \\
\hline Kolesterol Total (mg/dl) & $169,79^{\mathrm{b}}$ & $152,28^{\mathrm{ab}}$ & $171,53^{\mathrm{b}}$ & $145,24^{\mathrm{a}}$ \\
LDL (mg/dl) & $90,13^{\mathrm{c}}$ & $74,77^{\mathrm{b}}$ & $67,91^{\mathrm{ab}}$ & $54,78^{\mathrm{a}}$ \\
Trigliserida (mg/dl) & 142,11 & 156,53 & 142,24 & 139,97 \\
HDL (mg/dl) & 61,62 & 70,81 & 67,60 & 69,01 \\
\hline
\end{tabular}

Ket.: Superskrip yang berbeda pada baris yang sama menunjukkan perbedaan yang nyata $(\mathrm{p}<0,05)$. K1: ampas teh hijau fermentasi $0 \%, \mathrm{~K} 2$ : mpas teh hijau fermentasi $1 \%$; K3: ampas teh hijau fermentasi 2\%; K4: ampas teh hijau fermentasi 3\%

total terendah dihasilkan oleh perlakuan K4. Kondisi ini berarti ampas teh hijau fermentasi pada dosis 3\% diduga mampu menghambat sintesis asam mevalonat sehingga kolesterol yang dihasilkan oleh hati maupun darah menjadi menurun kadarnya (Agarwal dan Rao, 2000; Sukmawati dkk, 2014). Dengan demikian sintesis kolesterol yang akan terbentuk dalam jaringan atau hati menjadi menurun sehingga kolesterol yang terakumulasi di dalam daging menjadi menurun juga. Oleh karena kadar kolesterol darah menurun maka akan diikuti dengan menurunnya kadar trigliserida, HDL dan LDL.

KadarkolesteroltotaldanLDLmenunjukkan adanya perbedaan yang nyata $(\mathrm{P}<0,05)$ antar perlakuan pakan yang ditambahkan ampas teh hijau fermentasi. Perlakuan pakan K4 memiliki kadar kolesterol total yang paling rendah dibandingkan perlakuan pakan lainnya (K1, K2 dan K3). Kadar kolesterol darah yang menurun pada K4 disebabkan oleh adanya peningkatan senyawa antioksidan seiring dengan meningkatnya level ampas teh hijau fermentasi dalam pakan. Yunarto dkk. (2019) melaporkan bahwa senyawa antioksidan memiliki kemampuan untuk menghambat aktivitas enzim HMG Co-A reduktase yang akan mengubah 3-hidroksi, 3-metil, gluteril-Co-A menjadi asam mevalonat. Asam mevalonat ini merupakan senyawa awal di dalam proses pembentukan kolesterol darah. Penelitian lainnya melaporkan bahwa adanya proses penghambatan aktivitas enzim HMG Co-A reduktase pada perlakuan pakan yang mengandung antioksidan seperti perlakuan ATHF ini dapat menyebabkan turunnya penyerapan kolesterol di dalam saluran pencernaan dan kadar kolesterol darah (Joseph dkk., 2002; Tugiyanti dkk., 2016).

Kadar LDL hasil penelitian ini berkisar antara 54,78 mg/dl (K4) - 90,13 mg/dl (K1). Basmacioglu dan Ergul (2005) dalam Septinova dkk. (2020) melaporkan bahwa kadar LDL itik jantan adalah $<130 \mathrm{mg} / \mathrm{dl}$. Kondisi ini menunjukkan kadar LDL itik hasil penelitian masih dalam kisaran normal. Perlakuan pakan yang mendapatkan tambahan ATHF pada dosis semakin tinggi menunjukkan terjadinya penurunan LDL plasma itik yang semakin nyata. Hal ini diduga disebabkan oleh senyawa antioksidan pada dosis ATHF yang lebih tinggi (3\%) mampu menurunkan emulsi lemak dan sistesis kolesterol sehingga akan menurunkan kadarnya di dalam darah maupun daging itik. Senyawa polifenol dan flavonoid merupakan antioksidan yang terkandung di dalam ampas teh hijau fermentasi mampu menurunkan kadar kolesterol dengan cara meningkatkan eksresi garam empedu di dalam usus. Garam empedu ini berperan sebagai pengemulsi lemak di dalam usus yang dibentuk oleh kolesterol di dalam hati. (Pagala dan Agustina, 2009; Tugiyanti dkk., 2016). Tugiyanti dkk. (2016) menambahkan bahwa senyawa tannin yang masih terkandung pada perlakuan ATHF memiliki dampak hipoglikemik yang mampu menurunkan kadar kolesterol dan trigliserida darah.

Kadar LDL itik Cihateup pada perlakuan K1 lebih tinggi dibandingkan perlakuan lainnya (K2 - K4). Kondisi ini menunjukkan bahwa penambahan ampas teh hijau fermentasi pada level 1-3\% terbukti mampu menurunkan kadar LDL itik Cihateup. Penurunan kadar LDL pada perlakuan ATHF iniseiring dengan menurunnya kadar kolesterol total. Hal ini menunjukkan adanya korelasi yang positif antara parameter kolesterol total dan LDL. Dihansih dkk (2019) melaporkan bahwa menurunnya kadar kolesterol darah akan diikuti dengan kadar LDL karena keduanya memiliki korelasi positif. Semakin tinggi kadar kolesterol total maka akan diiringi dengan adanya peningkatan kadar LDL plasma itik, begitupun sebaliknya (Arini 2016; Septinova dkk., 2020). Montgomery dkk. (1993) 
dalam Dihansih dkk. (2019) menambahkan bahwa LDL berperan di dalam menyediakan kolesterol dalam jaringan tubuh karena berperan sebagai karier utama untuk kolesterol dari hati ke jaringan perifer sehingga kadar LDL dalam darah dipengaruhi oleh konsentrasi kolesterol.

Parameter kadar trigliserida dan HDL itik hasil penelitian menunjukkan tidak adanya perbedaan yang nyata $(\mathrm{P}>0,05)$. Secara statistika kadar HDL ini tidak menunjukkan adanya perubahan yang signifikan dengan adanya penambahan ampas teh hijau fermentasi. Hasil ini sejalan dengan penelitian Dihansih dkk (2019) yang melaporkan bahwa apabila kadar HDL meningkat maka kadar kolesterol, trigliserida dan LDL akan menurun. Hasanuddin dkk (2014) menambahkan bahwa HDL memiliki korelasi yang positif dengan LDL dan keduanya (HDL dan LDL) sangat dipengaruhi oleh kadar kolesterol darah. Meskipun pada penelitian ini hanya terjadinya penurunan pada parameter kolesterol total dan LDL saja.

Kadar trigliserida hasil penelitian berkisar antara 139,97 - 142,24 mg/dl. Tugiyanti dkk (2016) menjelaskan bahwa kadar trigliserida darah sangat dipengaruhiolehkadarkarbohidrat pakan. Trigliserida dibentuk di hati dengan mengkonversi karbohidrat menjadi asam lemak bebas. Dengan demikian trigliserida darah itik akan meningkat apabila itik diberikan pakan yang mengandung karbohidrat yang berlebih. Pada keempat perlakuan pakan yang dilakukan penelitian ini mengandung kadar karbohidrat yang relatif sama sehingga menghasilkan kadar trigliserida yang hampir sama. Kadar trigliserida sangat berhubungan dengan kadar gliserol dan asam lemak yang terdapat pada ransum.

Kadar HDL itik berkisar antara 61,62 $70,81 \mathrm{mg} / \mathrm{dl}$ yang menunjukkan bahwa hasil penelitian ini masih dalam kondisi normal. Mustikaningsih (2010) dalam Septinova dkk. (2020) melaporkan bahwa kadar HDL itik yang baik yaitu $>60 \mathrm{mg} / \mathrm{dl}$. Semua perlakuan menghasilkan kadar HDL yang lebih besar dari $60 \mathrm{mg} / \mathrm{dl}$ dimana perlakuan pakan yang diberi tambahan ampas teh hijau fermentasi menghasilkan nilai HDL yang relatif lebih tinggi.

\section{KESIMPULAN DAN SARAN}

\section{Kesimpulan}

Penambahan ampas teh hijau fermentasi sampai level 3\% sebagai imbuhan pakan itik Cihateup mampu menurunkan kadar kolesterol total dan LDL itik Cihateup namun tidak menurunkan kadar trigliserida dan meningkatkan LDL itik Cihateup.

\section{Saran}

Penambahan ampas teh hijau fermentasi pada dosis 3\% dapat diaplikasikan sebagai imbuhan pakan itik atau unggas lainnya sebagai upaya memperbaiki profil lipid darah.

\section{DAFTAR PUSTAKA}

Agarwal, S., and A. V. Rao. 2000. Role of antioxidant lycopene in cancer and heart disease. J. Coll. Nutr., (19 (5): 563 - 569.

Arini, N. M. J. 2016. Evaluasi Penggunaan Tepung Daun Indigofera zollingeriana dan Minyak Lemuru dalam Ransum terhadap Metabolisme Lipida Itik. Tesis. Institut Pertanian Bogor, Bogor.

Basmacioglu, H., and M. Ergol. 2005. Research on the factor affecting cholestrol content and some other characteristics of eggs laying hens. Turk J. Vet. Anim. Sci., 29: 157164.

Dihansih, E., D. Kardaya, dan D. Wahyuni. 2019. Performa dan profil lemak darah itik afkir yang diberi tepung daun asam gelugur pada ransum nonkonvensional terfermentasi. Jurnal Peternakan Nusantara, 5(2): 105110.

Ermayanti, N. G. A. M., I. G. L. Oka, I. G. Mahardika, dan I. P. Suyadnya. 2018. Profil lipid kelinci (Lepus sp.) jantan lokal yang diberi pakan komersial disuplementasi minyak hati ikan kod. Jurnal Biologi Udayana, 22(1): 7-12.

Fajar, R. I., L. P. Wrasiati, dan L. Suhendra. 2018. Kandungan senyawa flavonoid dan aktivitas antioksidan ekstrak teh hijau pada perlakuan suhu awal dan lama penyeduhan. Jurnal Rekayasa dan Manajemen Agroindustri, 6(3): 196-202.

Handayani, D., A. Mun'im, and A. S. Ranti. 2014. Optimation of green tea waste axtraction using microwave assisted extraction to yield green tea extract. Trad. Med. J., 19(1): 29-35.

Hasanuddin, S, V. D. Yunianto, dan Tristiarti. 2013. Profil lemak darah pada ayam broiler yang diberi pakan step down protein 
dengan penambahan air perasan jeruknipis sebagai acidifier. Jurnal Ilmu dan Teknologi Peternakan, 3(1): 11-17.

Joseph, G., H. T. Uhi, Rukmiasih, I. Wahyuni, S. Y. Randa, H. Hafid, dan A. Parakkasi. 2002. Status kolesterol Itik Mandalung dengan pemberian serat kasar dan vitamin E. Prosiding Seminar Nasional Teknologi Peternakan dan Veteriner 2002, Bogor.

Kusmayadi, A., R. S. Sundari, dan K. R. Bachtiar. 2020. Suplementasi ampas teh hijau fermentasi pada pakan terhadap performa dan income over feed cost itik Cihateup. Jurnal Ilmu dan Teknologi Peternakan Tropis, 7(3): 233-237.

Martina, S., dan F. Abdillah. 2020. Pola komersialisasi teh hijau pada industri hospitality: pandangan pelaku usaha. Sadar Wisata: Jurnal Pariwisata, 3(1): 1-12.

Montgomery, R., R. L. Dryer, T. W. Conway, and A. A. Spector. 1993. Biochemistry: A Case - Oriented Approach. Gadjah Mada University Press, Yogyakarta.

Mustikaningsih, F. 2010. Pengaruh Pemberian Berbagai Level Ekstrak Kunyit terhadap Kadar Kolesterol,High Density Lipoprotein dan Low Density Lipoprotein dalam Darah pada Ayam Broiler. Skripsi. Fakultas Peternakan Universitas Diponegoro, Semarang.

Ngantung, M. R., R. Dewi, dan J. L. Manalu. 2020. Perbandingan efektivitas teh hijau dan teh hitam dalam menurunkan kadar trigliserida pada hewan coba model hiperlipidemia. Damianus Journal of Medicine, 19(2): 118-124.

Nindyasari, S. 2012. Pengaruh suhu dan waktu penyeduhan teh hijau (Camellia sinensis) serta proses pencernaan in vitro terhadap aktivitas inhibisi lipase. Skripsi. Fakultas Teknologi Pertanian, Institut Pertanian Bogor, Bogor.

Pagala, M. A., dan D. Agustina. 2009. Kualitas kolesterol itik Tegal dengan pemberian seledri (Apium graviolens) dan dedak padi. Warta-Wiptek, 17: 97-100.
Saqifah, N., E. Purbowati dan E. Rianto. 2010. Pengaruh ampas teh dalam pakan konsentrat terhadap konsentrasi VFA dan $\mathrm{NH}_{3}$ cairan rumen untuk mendukung pertumbuhan sapi Peranakan Ongole. Makalah Dipresentasikan pada Seminar Nasional Teknologi Peternakan dan Veteriner. pp. 205-210.

Septinova, D., F. Fathul P. E. Santosa, dan M. Hartono. 2020. Profil lemak darah itik lokal jantan yang diberi campuran bahan pakan lokal yang difermentasi dengan Effective Microorganism-4. Jurnal Ilmiah Peternakan Terpadu, 8(3): 96-101.

Sukmawati, N. M. S., I. W. Wirawan, A. A. A. S. Trisnadewi, dan T. G. B. Yadnya. 2014. Lemak tubuh dan profil lipida darah itik bali jantan yang diberi ransum mengandung daun ubi jalar ungu (Ipomoea batatas L) disuplementasi starbio dan pignox (starpig). Majalah Ilmiah Peternakan, 17(1): 15-19.

Thrall, M. A., G. Weiser, R. Allison, and T. W. Campbell. 2012. Veterinary hematology and clinical chemistry. John Wiley and Sons, New York.

Tugiyanti, E., S. Heriyanto, A. N. Syamsi. 2016. Pengaruh tepung daun sirsak (Announa muricata L) terhadap karakteristik lemak darah dan daging itik tegal jantan. Buletin Peternakan, 40(3): 211-218.

Yulianti, W., W. Murningsih, dan V. D. Y. B. Ismadi. 2013. Pengaruh penambahan sari jeruk nipis (Citrus aurantifolia) dalam ransum terhadap profil lemak darah itik Magelang jantan. Anim. Agric. J., 2(1): 5158.

Yunarto, N., N. Aini, I. Sulistyowati, I. S. Oktoberia, dan A. A. Kurniatri. 2019. Aktivitas antioksidan serta penghambatan HMG-CoA dan lipase dari kombinasi ekstrak daun binahong-rimpang temulawak. Jurnal Kefarmasian Indonesia, 9(2): 89-96. 